\title{
UPLATNĚNÍ METODY ALTERNATIVNÍCH DOTAZŮ PŘI ZKOUMÁNÍ MOTIVACE
}

\author{
Jitka Březinová* ${ }^{*}$ Tatiana Čorejová ${ }^{* *}$
}

\section{Úvod}

V každé ekonomice jsou odvětví, bez nichž se žádný subjekt neobejde, která uspokojují některé klíčové potřeby a která také významně přispívají k růstu celkové produktivity práce. Poštovnictví je odvětví služeb, které má oproti výrobním odvětvím významná specifika - služba se spotřebovává samotným svým výkonem, nedá se uchovat do zásoby. Služba znamená bezprostřední kontakt mezi zákazníkem a poskytovatelem služby, v prrípadě pošty je její zaměstnanec tím, kdo svou činností klíčovým způsobem ovlivňuje kvalitu poskytované služby i vnímání pošty jako instituce.

$\mathrm{K}$ tomu, aby zaměstnanec pošty vykonával svou práci v souladu s hodnotami a cíli pošty, musí být ve své práci motivován. Práce v poštovnictví klade velké nároky na důvěryhodnost, poctivost a úctu k soukromí zákazníka, klade velké nároky na charakterové vlastnosti zaměstnance i jeho psychiku. Mnozí poštovní zaměstnanci jsou pro řadu lidí spojovacím článkem s okolním světem, důvěrníky i pomocníky, což klade velké nároky na jejich sociální inteligenci, komunikativnost, spolehlivost a diskrétnost.

V soutěži mezi podniky o př́zeň zákazníků hrají motivovaní zaměstnanci poskytující kvalitní výkon významnou roli a v podmínkách, kdy se podniky mezi sebou př́liš neliší používanou technologií, přístupem k informacím ani možností přístupu na trhy, jsou takoví zaměstnanci klíčovou konkurenční výhodou.Česká pošta, s. p. je v současné turbulentní době vystavena tlaku ekonomické situace, nárokům ze strany státu i zákazníků, i poměrně silnému konkurenčnímu boji a prochází neustálými změnami. V této situaci jí motivovaní zaměstnanci mohou významným způsobem pomoci. Česká pošta, s. p. má v současnosti 3392 pošt, kde pracuje téměř 30000 zaměstnanců, z kterých je prribližně 80 manažerů pošt, 4600 vedoucích a administrátorů, 12200 doručovatelů, 7000 pracovníků přepážek, 760 pokladníků a téměř 3000 pracovníků vnitřní služby.

Problematika motivace pracovního jednání má i v odvětví poštovnictví velký význam, protože správně nastavený motivační systém může přispívat k lepšímu pracovnímu výkonu, vyšší kvalitě služeb, lepším hospodářským výsledkům podniku i posílení jeho pozice na trhu.

Otázka motivace je multidisciplinární a může mít mnoho rovin zkoumání. Souvisí s teorií organizace a řízení lidských zdrojů. Úzce souvisí také s potřebami a preferencemi lidí, psychologií a sociologií jejich chování. Je realizována v konkrétním podniku, a to různými prostředky a nástroji s různým výsledkem. Souvisí s postavením podniku a jeho současnými i

\footnotetext{
${ }^{*}$ Ing. Jitka Březinová, externá doktorandka, Katedra spojov, Fakulta PEDAS, Žilinská univerzita v Žiline ${ }^{* *}$ prof. Ing. Tatiana Čorejová, PhD., Katedra spojov, Fakulta PEDAS, Žilinská univerzita v Žiline, e-mail: tatiana.corejova@fpedas.uniza.sk

${ }^{* *}$ prof. Ing. Tatiana Čorejová, PhD., Katedra spojov, Fakulta PEDAS, Žilinská univerzita v Žiline, e-mail: tatiana.corejova@fpedas.uniza.sk
} 
minulými charakteristikami. Odráží se v jednání lidí i jejich spokojenosti s prací a pracovní pozicí. Je předpokladem pro dosahování cílů podniku i osobních cílů zaměstnanců. Znalost problematiky motivace a možností její praktické aplikace $\mathrm{v}$ daném prostředí umožňuje vytvořit systém motivace, který může významně pomoci podniku v dosahování jeho cílů, ale i v dosažení konkurenční výhody vůči jiným podnikům. To může sloužit jako jeden ze zdrojů plánování a rozhodování, vytváření strategie dalšího rozvoje i taktiky uskutečňování praktických činností.

Při zkoumání jednotlivých problémů motivace je možné použít různé metody a jednou $\mathrm{z}$ nich je aplikace metody alternativních dotazů u panelu expertů, který byl sestaven $\mathrm{z}$ vedoucích střediskových pošt (20) a kterým byl dán prostor, aby se na základě inovativního přístupu vyjádřili ke klíčovým problémům v oblasti motivace.

Otázky, které měly blíže postihnout danou problematiku, bylo v určitých prípadech nutno formulovat tak, aby byl dán prostor $\mathrm{k}$ širší výměně názorů, což v následující fázi působí částečné komplikace s analýzou a kvantifikací získaných výsledků.

\section{Základní okruhy zkoumaných otázek}

V rámci aplikace metody alternativních dotazů bylo vytvořeno celkem pět okruhů otázek, které se týkaly vztahu k podniku a profesi, atmosféry na pracovišti, osobní spokojenosti, pohledu na nadřízeného a možností zlepšování procesu motivace v podniku. U většiny otázek byly dány varianty různých odpovědí pro prvotní inspiraci. Účastníci diskuse tedy vedoucí střediskových pošt si mohli předem odpovědi promyslet a některé i zaznamenat, v další diskusi pak byly získány další odpovědi a náměty. Tyto odpovědi byly účastníky zaznamenány písemně až po diskusi.

1. okruh otázek souvisel s tím, jak veřejnost, a také účastník vnímají podnik pozitivně či negativně, a jak vnímají profesi:

- v čem vidíte pozitivní hodnocení podniku $\mathrm{v}$ očích veřejnosti,

- v čem vidíte negativní hodnocení podniku v očích veřejnosti,

- jaké jsou slabiny a co je největším nebezpečím pro podnik,

- jak veřejnost vnímá vaši profesi,

- čeho si na podniku nejvíc vážím,

- co mi na podniku nejvíc vadí.

U těchto otázek šlo nejen o konstatování skutečnosti, ale součástí variant možných odpovědí byla i otázka na př́íčinu: proč?

2. okruh otázek zkoumal atmosféru na pracovišti:

- jste spokojeni s úrovní vzájemného chování v pracovním kolektivu,

- jaká je sociální atmosféra na vašem pracovišti (bylo popsáno 8 znaků a byla k dispozici škála o 8 stupních k vyjádření intenzity dané charakteristiky),

- jakou formu předcházení konfliktům považujete za nejúčinnější.

3. okruh otázek mapoval různé aspekty osobní spokojenosti účastníka:

- jste celkově spokojen se svým zaměstnáním,

- uvažujete o odchodu k jinému podniku a proč,

- obáváte se ztráty zaměstnání,

- jste spokojen/a s výší svého výdělku ve srovnání s výsledky v obdobných profesích $\mathrm{v}$ regionu,

- jste spokojen/a s možnostmi seberealizace.

V 4. okruhu otázek účastníci hodnotili své nadřízené:

- jakými principy se řídí váš nadřízený,

- kterých manažerských dovedností si u vedoucího ceníte nejvíce, 
- čem by vás měl nadřízený lépe a včas informovat,

- jaké je hodnocení pracovního výkonu nadřizeným,

- co by měly manažerům ukázat analýzy, studie a výzkumy realizované na pracovišti,

- jak celkově hodnotíte svého prímého nadřízeného.

5. okruh otázek se týkal možností zlepšení v oblasti motivace, a to jak ze strany manažerů ve vztahu k vedoucím střediskových pošt, tak ze strany vedoucích střediskových pošt ve vztahu k zaměstnancům:

- v jaké oblasti zaměstnaneckých výhod byste uvítal/a vy̌šsí příspěvky od zaměstnavatele,

- dá se práce na vašem pracovišti zvládnout s nižším počtem zaměstnanců, kdyby se mzda pracovníka, který odejde, mohla rozdělit mezi ostatní,

- jak zlepšit pracovní ovzduší v podniku,

- jaké metody vedoucí nejčastěji používá při prosazování a uskutečňování svých záměrů,

- váš osobní přínos - čemu byste se chtěl/a především věnovat v rámci zdokonalování a rozvoje,

- co by u vás nejvíc zvýšilo motivaci při plnění pracovních úkolů,

- váš osobní přínos - jakou konkrétní formu (metodu) pro zajištění stálé motivace zaměstnanců uplatňujete v praxi.

\section{Vyhodnocení diskuse}

Diskuse k prvnímu okruhu otázek neboli aspektů ukázala, že účastníci se z titulu své funkce (vedoucí střediskových pošt) intenzivně zajímají o to, jak jejich činnost i práce jejich podřizených působí navenek. Bylo zřejmé, že dobrý výsledek chápou nejen jako vizitku své práce, ale i jako příspěvek k vytváření dobrého jména pošty. Většina účastníků se ukázala být silně motivovaná a to se odráželo v jejich odpovědích.

Jako důvod pozitivního hodnocení podniku se nejčastěji vyskytovala dostupnost služeb (v poslední době rovněž dostupnost informací o poskytovaných službách, možnost sledovat pohyb zásilek na internetu, apod.), široká škála a kvalita poskytovaných služeb, ochota a znalosti pracovníků pošty, spolehlivost, lidský přístup a důvěra v zaměstnance (zejména $\mathrm{v}$ malých městech a obcích jde o osobní kontakt mezi zaměstnancem pošty a zákazníkem), vyvolávací systém. A v neposlední řadě také tradice a modernizace podniku.

Naopak negativní hlediska jsou spatřována zejména v setrvačnosti, konzervativnosti, nekvalitní práci zaměstnanců (zejména doručování zásilek, nešetrném zacházení se zásilkami, nerespektování individuálních požadavků zákazníka), špatném mediálním obraze, dlouhých čekacích dob, vyvolávacím systému, nevyhovujících hodinách pro veřejnost na malých poštách, byrokracii vůči klientům, náročnosti produktů, neinformovanosti veřejnosti.

$\mathrm{Na}$ těchto odpovědích je vidět, jak rozdílně mohou být jednotlivé aspekty vnímány. Velkou roli zde hraje místní hledisko. Co je na jednom místě považováno za klad, na jiném místě je přijímáno zcela negativně.

Rozsáhlá diskuse byla vedena o otázce, týkající se slabin a nebezpečí pro podnik. Je zřejmé, že možné faktory každý vnímá zcela individuálně, takže se projevila různost názorů. Pro účastníky bylo těžké zvolit jeden faktor, který je z jejich pohledu klíčový. Většinou uváděli řadu faktorů, a to spíše na základě intuice, než že by je dokázali adekvátně zhodnotit. Podle sídla dané střediskové pošty jsou také různě pocit’ována slabá místa a hrozby. Ve městech se spíše obávají konkurence jiných operátorů na poštovním trhu a někdy nezájmu zaměstnanců. V menších sídlech není prakticky konkurence a počet zaměstnancủ je nízký, takže je na každého vidět. Účastníci $\mathrm{z}$ menších sídel nepocit’ovali slabiny a hrozby tak intenzivně. Spíše se obávali některých nekompetentních kroků ze strany nadřízených - např́. stanovení otevírací doby. $\mathrm{V}$ rámci připravovaných změn $\mathrm{v}$ poště je ve hře např̀. pojízdná 
pošta, která by nahradila některé místní pošty, jsou s tím však spojené problémy bezpečnost zaměstnanců, dostupnost služby, časová náročnost pro zaměstnance atd.

I vnímání veřejnosti do značné míry závisí nejen na vedoucích pracovnících, ale na každém zaměstnanci, se kterým přichází zákazník do styku. Práci jednotlivých zaměstnanců může do jisté míry ovlivnit vedoucí pošty tím, jak dokáže své zaměstnance motivovat nejen $\mathrm{k}$ větší produktivitě práce, ale i k neustále se zvyšujícím nárokům na kvalitu odvedené práce. V dnešní době je těžké získat nového klienta, ale ještě těžší je si udržet klienty stávající, to se daří pouze v př́ípadě, že budou se službami spokojeni.

Účastníci panelu si na podniku nejvíce váží poskytování jistoty zaměstnání a umožnění osobního rozvoje zaměstnanců. Na stejném podniku jim pak nejvíce vadí nízká mzda pro podř́zené zaměstnance, neustále narůstající počet předpisů a pravidel, nedostatek nástrojů pro postih zneužívání pracovní neschopnosti, dlouhá procedura rozvazování pracovního poměru z důvodu porušování pracovní kázně či nekvality, neujasněnost koncepce a organizační struktury.

Diskuse $\mathrm{k}$ druhému okruhu směřovala $\mathrm{k}$ vnitřnímu prostředí na každé střediskové poště. Všichni účastníci jsou jednoznačně spokojeni súrovní vzájemného chování v pracovním kolektivu. Samožrejmě, že se mohou objevovat některé problémy, v převážné většině př́padů se však daří neustálým vysvětlováním a komunikaci se zaměstnanci vyvolat v nich pocit sounáležitosti k podniku, ukázat jim, že i spolupráce mezi jednotlivými skupinami zaměstnanců (doručovatelé - přepážkoví pracovníci - pracovníci vnitřní služby atd.) jim přinese určité výhody, že jedině v takovém prostředí se jim bude dobře pracovat.

Pokud jde o úroveň sociální atmosféry, byla dána účastníkům panelu škála možností zahrnující 8 znaků (přátelská - neprátelská, uklidňující - znervózňující, spolupracující konfliktní, nadšená - znechut'ující, upřímná - neupřímná, zajímavá - nudná, podporující lhostejná, produktivní - neproduktivní), a to proto, aby mohli být pocity výstižně vyjádřeny. Kromě toho byla dána škála intenzity každého znaku, čítající 8 stupňů od 1 - kladný znak charakterizuje atmosféru až po 8 - negativní znak je př́iznačný. U většiny charakteristik se účastníci pohybovali v rozmezí intenzity $2-3$, což znamená, že celkem jednoznačně převažuje pozitivní charakteristika. Pouze u znaku 2 a 4 byli kritičtější a přikláněli se k negativní charakteristice až na stupeň 6 - u charakteristiky znervózňující a znechut'ující.

Z následné diskuse vyplynulo, že tyto odpovědi měly prŕčinu vorganizačních změnách, které probíhají v poště postupně (již velice dlouhou dobu) a nejčastěji se dotýkají právě skupiny zaměstnanců, která se zúčastnila této diskuse.

$\mathrm{Na}$ ostatní odpovědi měla vliv skutečnost, že se jedná o prostředí, jehož nejvyšší představitel vlastně toto prostředí vytváŕí, je za něj do jisté míry zodpovědný a v odpovědi na otázky jakoby skládal účty ze své práce.

I když je ovzduší v podniku dobré, nikdy se nelze zcela vyhnout konfliktům. Za nejúčinnější formu předcházení konfliktů na pracovišti je považováno jasné vymezení práv a povinností jednotlivců, a zejména zlepšení oboustranného toku informací.

Otázky ve druhém okruhu se zdají být na první pohled irelevantní tématu motivace, avšak je zřejmé, že pracovní atmosféra je pro zaměstnance nesmírně důležitým motivačním prvkem.

Třetí okruh otázek byl orientován na zkoumaní různých aspektů spokojenosti účastníků. Všichni účastníci vyjádřili celkovou spokojenost se svým zaměstnáním a nikdo $\mathrm{z}$ nich neuvažuje o odchodu k jinému podniku. Pokud by někdo z nich uvažoval o změně, důvodem odchodu by bylo prestižnější zaměstnání. Pouze dva účastníci se obávají ztráty zaměstnání a všichni oslovení jsou spokojeni s výší svého výdělku vzhledem k výdělkům v obdobných profesích v regionu. Všichni z dotazovaných jsou spokojeni s možnostmi seberealizace. Nabízí se otázka, z čeho tato jejich celková spokojenost plyne. Vyjdeme-li $\mathrm{z}$ věkové struktury i délky praxe $\mathrm{v}$ poště, a také $\mathrm{z}$ vnějších podmínek, zjistíme řadu důvodů, 
které mohou vyvolávat pocit spokojenosti. Účastníci jsou většinou středního věku, a tudíž jistota $\mathrm{v}$ životě i v zaměstnání je pro ně důležitou hodnotou. Velká část $\mathrm{z}$ nich pracuje v poště již delší dobu, takže zná svou práci, má za sebou určitý kariérní postup a před sebou perspektivu víceméně stálého zaměstnání. Zejména v současné době, kdy se zvyšuje nezaměstnanost, výrobní podniky propouštějí, je jistota zaměstnání velmi ceněna. Dnes ještě nelze říci, zda se snížená aktivita podniků odrazí i na poptávce po poštovních službách. Účastníci ještě nemohou vidět důsledky ekonomického poklesu, ale čeho se zejména obávají, a co jejich spokojenost může narušit, jsou připravované organizační a vlastnické změny, které poštu v nejbližší době čekají.

Čtvrtý okruh otázek se týkal hodnocení nadřizených s cílem najít faktory přispívající ke zvýšení efektivnosti motivace a z toho plynoucím lepším výsledkům práce. V prostředí českých podniků je tento prvek (hodnocení nadř́zených) nový a neznámý, neslučitelný s uměle vytvářenou gloriolou nedotknutelnosti a neomylnosti „šéfa“. Naopak, v západních, velmi progresivních podnicích hodnocení nadřízených podřizenými slouží TOP managementu, resp. vlastníkům k dosažení maximální koordinace úsilí všech zaměstnanců k dosahování podnikových cílů. Hodnocení manažeři (na základě pohovoru k výsledkům hodnocení s vlastníkem nebo vrcholovým manažerem) se pak stávají skutečnými lídry, znalými kvality nejen svých podř́zzených, ale i svých vlastních schopností, takže nedochází k disproporci mezi udělováním př́kazů a možnostmi jejich plnění. Pak může být reálně naplněna teze, že konkurenční převaha podniku je dána kvalitními lidmi na př́slušných postech.

$\mathrm{Na}$ otázku, jakým principem se řídí jejich nadřízený při odměňování se deset vedoucích domnívá, že zásluhovostí, čtyři podle situace a okolností a šest to nedokázalo posoudit. Zde byly probírány i jiné možnosti, napřr. rovnostářství, ale k této odpovědi se nepřipojil nikdo z oslovených.

Účastníci si u svého nadřízeného si nejvíce cení schopnosti rozhodování a vůdcovských schopností. Požadují od něj, aby je lépe a včas informoval zejména o situaci podniku a připravovaných změnách, a také o názorech vedení podniku na kvalitu a pracovní výkonnost jejich kolektivů.

Hodnocení pracovního výkonu nadřízeným vnímá polovina dotazovaných jako objektivní a spravedlivé, druhá polovina toto neumí posoudit, protože nikdy nebyli seznámeni s tím, jak je jejich nadř́zený hodnotí. V diskusi se probíralo, co by měly různé analýzy, studie a výzkumy realizované na pracovišti manažerům pomoci ukázat. Dle názoru diskutujících by měli především ukázat způsoby, jak podřizené lépe motivovat, řídit a vést.

Př́mého nadřízeného pak opět jedna polovina hodnotí jako člověka na svém místě, majícího autoritu, který dokáže naslouchat a prosazovat oprávněné zájmy, druhá část pak toto opět nedokáže posoudit. Otázka je, jestli nedokáže nebo si netroufá. Z odpovědí na tyto otázky je zřejmé, že všichni vedoucí střediskových pošt hodnotí svého prímého nadřízeného (= ředitel OZ) jako člověka na svém místě, avšak jsou velice kritičtí ke skutečnosti, že je jejich nadřizený natolik vytížen, že není v jeho silách (má pod sebou spoustu lidí na velkém území) z každým z nich mluvit osobně na pravidelných setkáních (u některých z nich byl za dva roky působení pouze jedenkrát), sdělit jim své mínění o nich i o záměrech podniku. Probíhá pouze velice neosobní jednání na pravidelných poradách, kde je však mnoho lidí (asi 40), a proto nepřichází v úvahu tyto otázky řešit.

Poslední, pátý okruh souvisel s možnostmi zlepšení v oblasti motivace. Že jde o velmi komplikované téma, se ukázalo hned při první otázce tohoto okruhu: v jaké oblasti byste uvítali vyšší příspěvky od zaměstnavatele? Každý účastník měl poměrně jasnou představu, a každý jinou. To ukazuje, že jde o problém subjektivní volby související s preferencemi každého jednotlivce. Najít proto systém žádoucí pro všechny, je velmi složité. 
Problematika zaměstnaneckých výhod je zaměstnanci velmi často chápána pouze formálně, jako samozřejmost, s vyhasínajícím motivačním nábojem. Vhodným řešením by mohlo být zavedení „cafeteria systému“, kdy se vytváŕí vhodná skladba zaměstnaneckých výhod, z nichž si zaměstnanci vybírají takovou kombinaci, která rozsahem odpovídá jejich pracovním výsledkům a nejlépe odpovídá jejich zájmům. Tak se vytváŕí tlak a zájem o čerpání jednotlivých benefitů tak, aby fungovaly nejen jako motivační pobídka, ale také byly zaměstnanci efektivně využívány.

U další otázky už ale zavládl jednotný názor (s jedinou výjimkou). Otázka zněla, zda se práce na daném pracovišti dá zvládnout s nižším počtem zaměstnanců, kdyby se mzda pracovníka, který odejde mohla rozdělit mezi ostatní? Na tuto otázku odpovědělo devatenáct z dvaceti dotazovaných, že rozhodně ne. Pouze jeden vedoucí byl toho názoru, že spíše ano, ale tato skutečnost by si vyžádala kvalitní posouzení, Tento jediný vedoucí ze všech nikdy nepracoval v provozní funkci na poště a ve všech jeho odpovědích se vyskytují jako motivace pouze peníze, a byl tedy netypickým účastníkem.

Při řešení způsobu, jak zlepšit pracovní ovzduší v podniku se většina zúčastněných shodla, že je třeba zlepšit komunikaci a mezilidské vztahy, otevřeně hovořit se svými podř́zenými a řešit jejich problémy. Následně se diskutovalo, jakou metodu využívají účastníci při prosazování a uskutečňování svých záměrů nejčastěji. Dvanáct lidí z dvaceti používá metodu týmového rozhodování, v jednom případě se zde objevil i systém „cukru a biče". V̌̌ichni se následně shodli, že se metody mohou různit podle situace.

V rámci zdokonalování a rozvoje by se účastníci chtěli věnovat především vedení lidí, komunikaci a delegování pravomocí. Přri otázce, co by, nejvíce zvýšilo motivaci při plnění pracovních úkolů, se na první místo dostalo lepší finanční ohodnocení, následováno perspektivou pracovního růstu. Dále se hovořilo o faktu, že zaměstnanci chtějí znát záměry a cíle úkolů, které mají splnit, jejich logiku a souvislosti.

Byla proto položena další otázka: Jakou konkrétní formu resp. metodu pro zajištění stálé motivace zaměstnanců uplatňujete v praxi? Na prvním místě jako odpověd' samozřejmě zaznělo, že mimořádnou finanční odměnu, kterou preferuje všech dvacet oslovených. Všichni se rovněž shodli na pochvale. V neposlední řadě se zde objevilo i vyslovení uznání na veřejném vystoupení, profesní růst, nebo darování květin či dárků od partnerů.

U tohoto posledního tematického okruhu, který se zabýval motivačními prvky, se rozvinula největší diskuse. Jen dvanáct vedoucích z dvaceti nenavrhuje nic nového, pouze požadují zachovat, co platí v současnosti. Z diskuse vyplynulo, že každý z př́itomných preferuje jiný druh zaměstnaneckých výhod, zejména př́spěvek na penzijní pojištění, př́spěvek na rekreaci, osobní sociální účet, odměny při životním a pracovním jubileu a stravování. Všechny tyto položky jsou již zaměstnancům do jisté míry poskytovány, nikdo nepřišel s žádnou novinkou, názory se rozcházely pouze při diskusi o výši těchto př́spěvků.

Projednávala se i otázka výše plnění a různorodosti produktů, které se poskytují pro alianční partnery. Plán je v některých př́ípadech natolik nadsazen, že není v možnostech pošty jej splnit, a tudíž se stává nezdravě nemotivující. Aby byl plán alespoň částečně naplněn, probíhá jedna motivační akce aliančních partnerů za druhou, často je není možné sledovat, natož plnit.

Nikdo neuváděl, že by se plnění úkolů mohlo zvýšit zkvalitněním řídící práce, či zlepšením komunikace uvnitř kolektivu. Neznamená to ale, že tyto skutečnosti jsou vyřešeny, nebo že se jim nepřikládá tak velká důležitost, jaká by jim př́islušela, protože část zaměstnanců odchází z práce právě kvůli neshodám v kolektivu, či s nadř́zeným. Dále nikdo z diskutujících neuváděl, že by zvýšilo motivaci lepší nefinanční hodnocení, i když ze zkušeností je zřejmé, že i nefinanční odměna některých motivačních akcí je tak lákavá, že splní stoprocentně svůj účel. 


\section{Závěry}

Pro budování zdravé podnikové kultury jsou velmi důležité pracovní vztahy. Pro zlepšení těchto pracovních vztahů je nezastupitelná role vedoucího. Jednotliví vedoucí se musí více angažovat do psychologie ,jsme na jedné lodi“ a potlačovat separatistické chování. Cílem manažera má být vytvoření takového klimatu, aby zaměstnanci pracovali v podniku jako na svém.

Z diskuse vyplynulo, že ne všichni pracovníci jsou obeznámeni s nějakou motivační teorií, s jejich principy, možností aplikace v praxi, takže prezentují svou řídící činnost způsoby a zkušenostmi, které načerpali v průběhu dosavadní praxe, resp. „kopírováním“ způsobu vedení kolektivu od svých dřivějších nadřízených. Negativa plynoucí z této skutečnosti lze $\mathrm{v}$ podstatě $\mathrm{v}$ krátké době odstranit školením neboli tréninkem o metodách soudobého managementu, který se sice neustále vyvijí, ale aplikace moderních prvků v soudobé praxi zaostává.

\section{Literatura}

[1] ADAIR, J., Efektivní motivace. Praha: Alfa Publ. 2004, ISBN 80-86851-00-1

[2] ARMSTRONG, M., Management a Leadership. (překlad Josef Koubek). Praha: Grada Publ. 2008, ISBN 978-80-247-2177-4

[3] BEDRNOVÁ, E., NOVÝ, I., Psychologie a sociologie ř́zení. Praha: Management Press 2007, ISBN 978-80-7261-169-0

[4] BĚLOHLÁVEK, F., Jak vést a motivovat lidi. Praha: Computer Press 2008, 978-80251-2235-8

[5] BĚLOHLÁVEK, F., Organizační chování: jak se každý den chovají spolupracovníci, nadřizení, podřizení, obchodní partneři či zákazníci. Olomouc: Rubico 1996, ISBN 8085839-09-1

[6] BRUCE, A., PEPITONE, J. S., Motivating Employees. McGraw-Hill 1999, ISBN 0-07071868-7

[7] CRAINER, S., Kompendium managementu - 50 knih, které změnily management. Praha: Computer Press 1998, ISBN 80-7226-109-6

[8] CRAINER, S., Moderní management. Základní myšlenkové směry. Praha: Management Press 2000, ISBN 80-7261-019-8

[9] KEŘKOVSKÝ, M., Moderní prístupy k ř́zení výroby. Praha: C. H. Beck 2001, ISBN 80-7179-471-6

[10] KIM, S. H., Tisic a jeden zpưsob jak motivovat sebe i druhé. Praha: Management Press 2008, ISBN 80-7261-078-3

[11] KLEIBL, J., DVOŘÁKOVÁ, Z., ŠUBRT, B., Řizení lidských zdrojů. Praha: C. H. Beck 2001, ISBN 80-7179-389-2

[12] KOCIANOVÁ, R., Personální ř́zení: teoretická východiska a vývoj. Praha: Eurolex Bohemia 2004, ISBN 80-86432-97-7

[13] KOCOUREK, J., TRYLČ, L., Mzda, plat a jiné formy odměňování za práci v $\check{C} R$. Olomouc: ANAG 2004, ISBN 80-7263-226-4

[14] KOONTZ, H., WEIHRICH, H., Management. Praha: Victoria Publishing 1993, ISBN 80-85605-45-7

[15] KOUBEK, J., Řizení lidských zdrojů. Praha: Management Press 2008, ISBN 978-807261-168-3

[16] KUBEŠ, M., SPILLEROVÁ, D., KURNICKÝ, R., Manažerské kompetence. Praha: Grada Publ. 2004, ISBN 80-247-0698-9 
[17] LEIGH, A., MAYNARD, M., The Perfect Leader. Random House Business Books 1999, ISBN 0-09-940622-5

[18] MAITLAND, I., Motivating people. Institute of Personnel and Development 1995, ISBN 0-85292-765-5

[19] MILKOVICH, G. T., BOUDREAU, J. W., Řizení lidských zdrojů. Praha: Grada Publ. 1993, ISBN 80- 85623-29-3

[20] NAKONEČNÝ, M., Motivace pracovního jednání a její ř́zení. Praha: Management Press 1992, ISBN 80-85603-01-2

[21] NIERMEYER, R., SEYFFERT, M., Jak motivovat sebe a své spolupracovníky. Praha: Grada Publ. 2005, ISBN 80-247-1223-7

[22] NÖLLKE, M., Praktický management (Jak úspěšně vést a ř́dit sebe, druhé lidi, firmy a jiné organizace.). Praha: Grada Publ. 2004, ISBN 80-247-0912-0

[23] PROVAZNÍK, V., KOMÁRKOVÁ, R., Motivace pracovního jednání. Praha: Oeconomica 2004, ISBN 80-245-0703-X

[24] RŮŽIČKA, J., Motivace pracovního jednání. Praha: VŠE 1995, ISBN 80-7079-626-X

[25] STÝBLO, J., Moderní personalistika. Praha: Grada Publ. 1998, ISBN 80-85424-92-4

[26] TEPPER, B. B., Manažerské znalosti a dovednosti. Praha: Grada Publ. 1996, ISBN 807169-471-6

[27] THORNE, K., PELLANT, A., Rozvíjíme a motivujeme zaměstnance. Praha: Computer Press 2008, 978-80-251-1689-0

[28] TOMŠÍK, P., Teorie motivace a odměňování pro řizení lidských zdrojů. Brno: MZLU 2005, ISBN 80-7157-845-2

[29] TURECKIOVÁ, M., Řizení a rozvoj lidí ve firmách. Praha: Grada Publ. 2004, ISBN 80247-0405-6

[30] VARADZIN, F., BŘEZINOVÁ, O., Hledání ve světě ekonomie. Praha: Professional Publ. 2003, ISBN 80-86419-56-8

[31] WERTHER, W. B., KEITH, D., Lidský faktor a personální management. Praha: Victoria Publ. 1992, ISBN 80-84605-04-X

[32] Zákon č. 262/2006 Sb., zákoník práce

[33] Zákon č. 309/2006 Sb., o zajištění dalších podmínek bezpečnosti a ochrany zdraví při práci, v platném znění

[34] Nařízení vlády č 168/2002 Sb., kterým se stanoví způsob organizace práce a pracovních postupů, které je zaměstnavatel povinen zajistit při provozu dopravy dopravními prostředky, v platném znění

[35] Nařízení vlády č. 589/2006 Sb., kterým se stanoví odchylná úprava pracovní doby a doby odpočinku zaměstnanců v dopravě, v platném znění

[36] Pracovní řád České pošty, s. p.

[37] Podniková kolektivní smlouva ČP na rok 2006 - 2010 v platném znění

[38] Externí a interní materiály České pošty, s.p.

\section{Grantová podpora}

Príspevok vznikol na základe riešenia výskumného projektu VEGA 1/4573/07 Možnosti, ohraničenia a vývojové tendencie koncepcie univerzálnej služby v pošte a telekomunikáciách v procese globalizácie . 